\title{
STRATEGI KOMUNIKASI KRISIS PUBLIC RELATIONS PT. LION MENTARI AIRLINES DALAM MERESPON KASUS KECELAKAAN PESAWAT LION AIR JT610
}

\author{
Muhammad Thoyib Amali \\ Magister Ilmu Komunikasi Universitas Diponegoro Semarang \\ thoyibamali@gmail.com
}

\begin{abstract}
Abstrak
Lion Air penerbangan JT610 yang beroperasi dari Jakarta ke Pangkal Pinang jatuh 13 menit setelah lepas landas pada 29 Oktober 2018 lalu menewaskan seluruh penumpang dan awak pesawat yang berjumlah 189 orang. Kecelakaan ini menyebabkan krisis yang menjadi perhatian publik terhadap maskapai penerbangan yang telah banyak dikeluhkan oleh pelanggan terkait manajemen pelayanan mereka. Menggunakan metode kualitatif deskriptif berdasarkan Situational Crisis Communication Theory (SCCT) dengan data yang dikumpulkan melalui dokumen berupa press release dan pemberitaan terkait kecelakaan tersebut, penelitian ini mencoba mengidentifikasi dan mendeskripsikan bagaimana Public Relations PT. Lion Mentari Airlines sebagai perusahaan yang mengoperasikan pesawat Lion Air menciptakan strategi untuk mengelola dan menangani krisis tersebut. Hasil dari penelitian ini menunjukkan bahwa Public Relations PT. Lion Mentari Airlines menggunakan gabungan strategi respon krisis primer antara strategi pengurangan (diminish) dan strategi pembangunan kembali (rebuild). Selain itu mereka juga menggunakan strategi respon krisis sekunder berupa strategi memuji (ingratiation) dan strategi korban (victimage).
\end{abstract}

Kata kunci: Komunikasi Krisis, Lion Air, Public Relations, Respon Krisis, SCCT.

\begin{abstract}
Lion Air Flight JT610 that operated from Jakarta to Pangkal Pinang crashed 13 minutes after takeoff on 29 October 2018, killing all 189 people on board. This accident causing crisis that drawing public attention towards the airlines that has been complained a lot by their customers about their services management. Using descriptive qualitative method based on Situational Crisis Communication Theory (SCCT) on data that collected through press release and news related to the accident, this research tries to identify and describe how Public Relations Department of PT. Lion Mentari Airlines, a company that operates Lion Air airlines creating strategies to manage and handle the crisis. This study shows that Public Relations Department of PT. Lion Mentari Airlines uses a combination of primary crisis response strategies between diminish strategies and rebuild strategies. In addition, they also used secondary crisis response strategies in the form of ingratiation strategies and victimage strategies.
\end{abstract}

Keywords: Crisis Communication, Crisis Response, Lion Air, Public Relations, SCCT. 


\section{Pendahuluan}

Transportasi udara di Indonesia saat ini mengalami perkembangan yang begitu pesat, hal tersebut dapat dilihat dari banyaknya maskapai penerbangan yang sekarang telah melayani berbagai rute baik domestik maupun internasional. Bahkan persaingan dalam jasa penerbangan ini pun semakin ketat dengan munculnya maskapai pesawat berbiaya murah atau low cost carrier. Sejak peraturan pemerintah mengenai industri jasa penerbangan di Indonesia mulai dilonggarkan pada tahun 2000, pertumbuhan jasa penerbangan di Indonesia melonjak tajam dalam satu dekade terakhir ini (kompas.com, 20 April 2016).

Lion Air merupakan salah satu maskapai penerbangan low cost carrier yang paling banyak digunakan oleh masyarakat Indonesia, bahkan dari laporan Global Flight Pricing yang dilakukan oleh Rome2Rio, sebuah perusahaan travel search engine dari Australia, maskapai ini termasuk ke dalam 10 maskapai termurah di dunia dengan tarif 0,10 USD atau setara dengan Rp 1.339 per km (viva.co.id, 22 Mei 2018). Di Asia sendiri maskapai ini menjadikan dirinya sebagai pemain Regional yang berkompetisi dengan AirAsia dari Malaysia di sektor low cost carrirer (merdeka.com, 24 Oktober 2014). Bahkan untuk untuk memperkuat operasionalnya di luar negeri, maskapai swasta terbesar di Indonesia dengan jaringan rute yang cukup luas ini telah melebarkan sayapnya dengan mendirikan Malindo Air dan Thai Lion Air (kompas.com, 20 Agustus 2013).

Meski menjadi salah satu maskapai yang laris digunakan, ternyata feedback yang diberikan oleh masyarakat indonesia kepada PT. Lion Mentari Airlines selaku perusahaan yang mengoperasikan Lion Air cenderung kurang baik. Banyak pelanggan yang mengeluhkan tentang buruknya pelayanan maskapai ini mulai dari pengembalian tiket, bagasi yang sering rusak atau hilang hingga delay berkepanjangan yang masih sering terjadi sampai sekarang. Yayasan Lembaga Konsumen Indonesia (YLKI) sendiri mencatat bahwa selama tujuh tahun terakhir laporan keluhan konsumen penerbangan Lion Air paling tinggi, terutama masalah delay (liputan6.com, 03 Nov 2018)

Banyaknya keluhan pelanggan tersebut merupakan bentuk nyata dari krisis yang dialami oleh perusahaan, meski begitu Lion Air tetap menjadi salah satu maskapai yang banyak digunakan dengan tingkat okupasi atau load factor yang mencapai 85-90 persen berdasarkan dari data maskapai pada akhir 2014. Salah satu alasan masih banyaknya penumpang Lion Air karena ada keunggulan Lion yang tidak dimiliki maskapai lain, di mana frekuensi penerbangan menjadi salah satu hal yang paling dipertimbangkan bagi para calon penumpang dibandingkan dengan harga tiket. Selain itu dengan semakin cepatnya pertumbuhan jumlah pesawat yang dimiliki Lion membuat masyarakat menjadi banyak pilihan waktu untuk dapat melakukan perjalanan (liputan6.com, 21 Februari 2015)

Pada tanggal 29 Oktober 2018 lalu Lion Air Penerbangan JT610, Boeing 737 MAX 8 dengan rute penerbangan Jakarta ke Pangkal Pinang sempat hilang kontak sebelum akhirnya 
diketahui terjatuh di perairan Tanjung Karawang 13 menit setelah lepas landas dan menewaskan seluruh 189 penumpang termasuk awak pesawat. Kecelakaan ini menjadi kecelakaan terparah kedua sepanjang sejarah penerbangan Indonesia, dalam hal jumlah korban, di mana sebelum kecelakaan JT610 maskapai Lion Air sendiri tercatat telah mengalami 11 kecelakaan besar (major accident). Sejak 2002, Lion Air telah mengalami total loss (kecelakaan yang menyebabkan pesawat tidak bisa dipakai lagi) sebanyak 5 pesawat, 5 kecelakaan dengan kerusakan besar, dan 1 minor loss (kompas.com, 31 Oktober 2018)

Peristiwa jatuhnya pesawat JT610 sendiri menjadi perhatian banyak publik, rasa simpati terhadap korban dan keingintahuan publik akan penyebab terjadinya kecelakaan membuat hal ini diperbincangkan banyak orang. Tidak hanya menjadi perhatian di Indonesia, peristiwa ini juga sudah jadi perbincangan dunia, di mana hastag \#JT610 menjadi salah satu tending worldwide. Pihak Lion Air sendiri memperlihatkan rasa duka mereka atas kecelakaan ini dengan mengubah seluruh akun media sosial mereka mulai dari Twitter, Facebook dan Instagram hingga situs resminya menjadi hitam putih. Terkait dengan kecelakaan ini juga Lion Air langsung membuka pusat krisis (crisis center) dan informasi penumpang (passenger information) dengan nomor yang bisa dihubungi oleh keluarga korban. (detik.com, 29 Oktober 2018).

Kecelakaan ini mendorong nitizen Indonesia untuk berkomentar terkait reputasi dan manajemen yang ada di Lion Air. Akun-akun sosial media Lion Air dipenuhi oleh komentar yang cenderung negatif saat kecelakaan ini terjadi. Seperti saat awal-awal krisis yang masih minim informasi, berbagai spekulasi yang tidak bertanggung jawab muali bermunculan di internet. Akhirnya banyak kabar bohong (hoax) yang beredar seputar kecelakaan ini. Kementerian Komunikasi dan Informatika (Kominfo) melaporkan setidaknya sudah ditemukan lima informasi palsu (hoax) yang beredar terkait kecelakaan ini, diantaranya foto badan pesawat terbelah, video jatuhnya pesawat, video penumpang yang panik, foto penumpang menggunakan masker hingga satu bayi korban selamat (detik.com dan kompas.com, 30 Oktober 2018)

Jatuhnya Peswat Lion Air JT610 ini merupakan kecelakaan terbesar yang dialami oleh Lion Air di mana peristiwa ini bisa dibilang merupakan puncak dari krisis yang selama ini ada di perusahaan mereka. Pesawat Boeing 737 MAX 8 yang digunakan oleh Lion Air dalam penerbangan JT610 merupakan pesawat yang relatif baru, di mana Lion Air mulai menggunakan pesawat ini pada bulan Agustus 2018 lalu dengan jam terbangnya masih sekitar 800 flight hour (kompas.com, 29 Oktober 2018). Kondisi pesawat yang masih baru ini menepis spekulasi kondisi pesawat yang tak layak terbang dan terdapat kebocoran tangki sebagai penyebab terjadinya kecelakaan, di mana Edward Sirait, CEO Lion Air mengatakan pesawat itu sempat mengalami masalah teknis yang tidak dirinci pada penerbangan sebelumnya, tetapi hal tersebut telah diatasi sesuai dengan prosedur yang ada (bbc.com, 29 Oktober 2018).

Terlepas dari apa yang menyebabkan jatuhnya pesawat tersebut. Kecelakaan yang 
dialami Lion Air ini menambah daftar krisis yang mereka alami. Secara tidak langsung tentunya citra dan reputasi perusahaan akan semakin memburuk, bahkan setelah kecelakaan ini menjadi perbincangan dunia para pejabat dan kontraktor pemerintah Australia telah diperintahkan untuk tidak terbang dengan menggunakan Lion Air ataupun anak maskapai penerbangan mereka (dailymail.co.uk, 29 Oktober 2018). Untuk itu upaya-upaya yang dilakukan oleh PR (Public Relations) Lion Air saat terjadi krisis tentunya harus mampu mengurangi persepsipersepsi negatif yang ada. Banyak ketidakpastian dan spekulasi yang muncul saat krisis ini terjadi, atau yang lebih parah lagi seperti yang sudah terjadi banyaknya hoax yang beredar di sosial media yang tentunya semakin bisa memperkeruh suasana.

Penanganan krisis yang baik oleh PR akan memberikan efek positif terhadap perusahaan, di mana para stakeholder dari perusahaan yang terkait akan lebih merasa tenang meski krisis telah terjadi. Bagaimanapun juga meski bisa dicegah, krisis merupakan hal yang tidak dapat dihindari (inevitable) apalagi saat krisis yang ada memakan korban yang banyak. Krisis biasanya menjadi perbincangan publik dan juga akan semakin membesar jika media gencar memberitakannya (Kriyantono, 2015: 200).

Berdasarkan uraian diatas, maka permasalahan yang muncul dalam penelitian ini adalah bagaimana strategi komunikasi krisis PR PT. Lion Mentari dalam mengelola dan merespon krisis akibat jatuhnya pesawat Lion Air JT610. Sedangkan tujuan dari penelitian ini adalah untuk mendeskripsikan strategi komunikasi krisis PR PT. Lion Mentari Airlines dalam mengelola dan merespon krisis akibat jatuhnya pesawat Lion Air JT610.

\section{Tinjauan Pustaka}

\subsection{Komunikasi Krisis}

Menurut Barton (1993:2) sebuah krisis adalah peristiwa besar yang tidak terduga dan secara potensial berdampak negatif terhadap organisasi dan publiknya. Kejadian ini bisa saja merusak organisasi, karyawan, produk atau jasa yang dihasilkan organisasi, kondisi keuangan hingga reputasi perusahaan. Hal tersebut bisa terjadi karena dalam situasi krisis, organisasi yang ada selalu menjadi sasaran pertama yang dimintai pertanggung jawaban.

Komunikasi dalam sebuah krisis berarti menyampaikan segala bentuk informasi, keterangan yang sejelas-jelasnya, tepat dan memiliki sifat segera atau urgent. Dalam merespon krisis, pemenuhan akan informasi yang terkontrol dengan baik dan informasi yang cepat dan tepat merupakan prioritas utama. Komunikasi krisis dirancang melalui program-program untuk meminimalisir kerusakan terhadap citra organisasi, di mana program-program tersebut merupakan bentuk dari strategi manajemen krisis yang diterapkan untuk menghilangkan sebagian risiko dan ketidakpastian dari kejadian negatif yang ada agar memungkinkan organisasi untuk mengendalikan nasibnya sendiri (Fearn-Banks, 2007:7). 
Komunikasi krisis dikatakan efektif jika organisasi atau perusahaan dapat melakukan tindakan dasar meminimalkan dampak negatif krisis yang ada bagi publik atau stakeholder mereka. Hal ini merupakan prinsip utama dalam pembuatan strategi komunikasi krisis, di mana dalam pembuatan strategi tersebut menurut Prayudi (1998:39) paling tidak organisasi harus mempertimbangkan publik mereka serta model dan tujuan dari strategi komunikasi untuk masing-masing publik yang tersebut. Pengenalan terhadap publik sasaran merupakan hal yang penting dalam program komunikasi krisis. Dengan pemahaman yang detail terhadap publik, dapat ditentukan cara komunikasi yang paling tepat agar pesan komunikasi krisis yang ada bisa diterima dan dipahami dengan baik agar tidak terjadi tumpang tindih informasi yang mengandung pertentangan hingga dapat memperkeruh suasana. Fearn-Banks (2007:261) membagi publik tersebut ke dalam kategori:

1. Enabling public, yakni publik yang mempunyai kekuasaan untuk memutuskan suatu persoalan dalam perusahaan. Termasuk di dalamnya antara lain Dewan Direktur, pemegang Saham, Komisaris perusahaan dan pemerintah.

2. Functional public, yakni kelompok orang yang menjadikan sebuah organisasi tetap aktif termasuk di dalamnya antara lain karyawan, konsumen, supplier, vendor, dll.

3. Normative public, yakni kelompok orang yang mempunyai kepentingan yang sama dengan organisasi. Termasuk di dalamnya adalah para anggota asosiasi perusahaan sejenis atau bahkan kompetitor.

4. Diffused public, yakni kelompok orang yang secara tidak langsung berhubungan dengan organisasi dalam sebuah krisis, seperti media dan kelompok-kelompok komunitas.

\subsection{Peran Public Relations dalam Komunikasi Krisis}

Salah satu kunci utama dalam komunikasi krisis di sebuah organisasi atau perusahaan adalah melalui peran Public Relations (PR). Menurut Indrayani (2017:68) PR dituntut untuk menjadi mediator, kreator, konseptor, sekaligus komunikator yang baik dengan cara mengoptimalkan dan memberdayakan apa yang ada dan berkembang dalam masyarakat, di mana hasil yang ingin dicapai dalam kegiatan PR pada intinya adalah good image (citra yang baik), goodwill (itikad baik), mutual understanding (saling pengertian), mutual confidence (saling mempercayai), mutual appreciation (saling menghargai), dan tolerance (toleransi).

Peran tersebut menjadi sangat penting ketika sebuah organisasi atau perusahaan mengalami krisis. PR dapat membantu perusahaan untuk menciptakan kondisi yang dapat membawa perusahaan yang sedang mengalami krisis kembali ke sedia kala. Hal itu hanya dimungkinkan bila praktisi PR mengenali gejala-gejala krisis yang ada dan melakukan tindakan tepat yang terintegrasi agar reputasi perusahaan tetap terjaga. Saat terjadi krisis publik sering kali mempertanyakan integritas dan menunjukkan kemarahan mereka terhadap perusahaan, bahkan para stakeholder pun dapat memutuskan hubungan mereka dengan perusahaan. Jika 
krisis tidak ditangani dengan baik oleh PR penyebaran komentar negatif tentang perusahaan akan menyebar dengan luas, terutama di era digital seperti ini. Munculnya e-WOM (Electronic Word of Mouth) yang negatif tentunya akan memperburuk reputasi perusahaan

Sebagai ujung tombak informasi perusahaan, PR harus mampu menjadi sumber referensi yang dipercaya oleh publiknya, di mana dalam upaya komunikasi krisis peran media sebagai saluran penyebaran informasi merupakan sasaran utama pihak PR. Beberapa bentuk penyampaian komunikasi krisis melalui media menurut Wasesa (dalam Sagala, 2015:50-51) dapat dilakukan oleh PR dengan cara sebagai berikut:

1. Press conference, perusahaan mengundang beberapa media massa untuk menghadiri konferensi mengenai krisis atau masalah yang dihadapi. Melalui konferensi ini perwakilan perusahaan atau spokesperson bertemu secara langsung dengan pihak media untuk menjelaskan rangkaian kronologis kejadian, memberikan fakta-fakta terkait masalah yang dihadapi serta meluruskan informasi yang salah atau belum tentu kebenarannya

2. Press release, merupakan pernyataan tertulis yang menjelaskan bagaimana perusahaan menangani krisis. Pernyataan tersebut pada umumnya dimuat media massa, atau saat ini bisa dipublikasikan melalaui website atau akun sosial media perusahaan. Press release ini juga dapat berisi kronologis dan perkembangan kejadian, permohonan maaf serta penanganan yang dilakukan pihak perusahaan.

3. Feeding Information, untuk menetralisirkan suara negatif dari pembuat opini publik yang kurang memahami situasi, dilakukanlah pemberian informasi kepada pembuat opini publik untuk menjelaskan keadaan yang sesungguhnya atau setidaknya pembuat opini publik mengetahui latar belakang yang menjadi penyebab krisis tersebut muncul.

4. Crisis Management Centre, pihak perusahaan perlu menyediakan pusat penanggulangan krisis yang berguna untuk kepentingan publik yang berhubungan dengan krisis atau kecelakaan yang dihadapi. Crisis Management Centre ini dapat berupa layanan telepon bebas pulsa, posko di tempat kejadian atau di kantor pusat perusahaan.

Dalam manajemen krisis yang lebih berorientasi terhadap keselamatan publik, menurut (Kriyantono, 2015:246-252) PR dapat menerapkan strategi komunikasi krisis yang dirancang dengan:

1. Mengatur tim manajemen krisis yang terpadu dengan koordinasi yang kuat dan diikat oleh perencanaan komunikasi krisis yang baik, termasuk pembagian kerjanya.

2. Mengurangi resiko munculnya shock, kepanikan dan kekhawatiran publik dengan mengumpulkan fakta-fakta dan mempersiapkan pernyataan kepada publik. Fakta-fakta harus di konfirmasi untuk memastikan tidak ada yang palsu ataupun miscommunication.

3. Mengurangi spekulasi-spekulasi khususnya di awal-awal krisis dengan mengontak media massa untuk memberikan tiga informasi dasar seperti: (a) inilah yang terjadi 
(termasuk siapa korban dan penyebabnya), (b) inilah yang telah kami lakukan (untuk masalah dan dampaknya) (c) inilah yang kami rasakan (sedih, prihatin, bela sungkawa, mohon maaf terlepas salah atau benar). Spekulasi yang dibiarkan akan memunculkan rumor yang memungkinkan lebih dipercaya, mempengaruhi persepsi dan dianggap sebagai kebenaran.

4. Melakukan konferensi pers secara berkala selama krisis berlangsung. Tujuannya untuk update informasi sehingga tidak muncul kekurangan informasi dan mengonter berita-berita atau publisitas yang negatif di media. Informasi yang negatif juga harus tetap disampaikan dengan cara yang tidak membuat reputasi perusahaan semakin memburuk.

5. Tetap berhati-hati dalam menyampaikan informasi, di mana dalam situasi krisis desakan media (media scrutiny) sangat besar, namun perusahaan tidak perlu terburuburu menyampaikan informasi yang masih belum jelas atau belum mempunyai fakta yang valid. Jika media masih mengejar untuk menggali informasi, memberi holding statement atau menyatakan bahwa fact finding yang masih berlangsung merupakan pilihan yang bijak.

6. Membuat sistem one gate communication melalui sebuah media centre dengan satu orang juru bicara (spokesperson). Seseorang yang ditunjuk sebagai juru bicara harus kredibel dan mengerti situasi krisis yang ada. Dalam menangani krisis juru bicara pendukung (endorser) juga perlu disiapkan.

7. Menunjukkan empati terhadap korban atau publik yang terkena dampak langsung dari krisis yang ada. Meskipun krisis bukan kesalahan organisasi, kata maaf, keprihatinan dan atau kesedihan yang mendalam perlu disampaikan

\subsection{Situational Crisis Communication Theory}

Situational Crisis Communication Theory (SCCT) merupakan sebuah teori yang digagas oleh W.T. Coombs dan Holladay S.J. Teori ini dapat digunakan untuk menjelaskan reaksi publik terhadap situasi krisis dan reputasi yang terjadi pada suatu organisasi. Teori ini juga menyediakan frame-work yang berguna untuk memahami bagaimana memaksimalkan perlindungan reputasi yang bisa dilakukan saat mengadakan komunikasi krisis (Coombs, 2007:164). Dasar dari SCCT sendiri dapat ditemukan melalui Teori Atribusi, yang menyatakan bahwa publik selalu mencari penyebab, atau membuat atribusi, untuk berbagai peristiwa, terutama jika peristiwa tersebut sangat negatif atau tidak terduga (Coombs. 2017:22).

SCCT juga dapat digunakan untuk memahami bagaimana respon stakeholder terhadap strategi krisis (crisis response) yang dibuat oleh praktisi PR, di mana dalam sebuah tim manajemen krisis PR biasanya bertindak sebagai manajer krisis. Respon stakeholder sendiri pada akhirnya menentukan evaluasi stakeholder terhadap reputasi organisasi, sehingga para 
stakeholder dapat memutuskan apakah mereka tetap berinteraksi dengan organisasi tersebut di masa yang akan datang atau tidak (Kriyantono, 2014:189).

Teori ini beranggapan bahwa pada dasarnya, publik mempunyai atribusi-atribusi tertentu mengenai krisis, dan hal tersebut menjadi penentu bagi reputasi sebuah organisasi. Atribusi pada dasarnya merupakan persepsi publik terhadap organisasi. Persepsi yang dihasilkan tidak muncul begitu saja, tetapi terdapat beberapa hal yang mempengaruhi munculnya sebuah persepsi terhadap organisasi (Kriyantono, 2015:318). Dalam teori ini, konsep utama yang mendasarinya adalah reputasi, di mana SCCT ini berfokus pada upaya menyelamatkan reputasi organisasi akibat terpaan krisis. Reputasi dapat dikatakan sebagai evaluasi publik mengenai kualitas organisasi dalam memenuhi harapan publiknya, seperti yang dikatakan oleh Coombs (2007:164) reputasi merupakan aset yang bernilai dan bersifat intangible atau tak terlihat secara fisik.

Reputasi sebuah organisasi sangat bergantung pada informasi yang tersebar dan diterima di kalangan publik, sehingga reputasi ini dapat dikatakan memiliki sifat yang evaluatif. Kebanyakan dari informasi yang tersebar dan diterima di kalangan publik berasal dari berita di media massa, WOM (word of mouth), atau bahkan di jejaring sosial media (Kriyantono, 2014:190-191). Munculnya internet dan sosial media yang dengan begitu bebas dan cepat menyebarkan informasi membuat publik menjadi dengan mudah terekspos berbagai informasi terkait krisis yang ada. Dua titik utama persinggungan antara media sosial dan SCCT melibatkan sifat publik yang meningkat dari fase pra krisis dan pemilihan saluran untuk komunikasi krisis. Dengan menjamurnya saluran, topik saluran menjadi menonjol (Coombs. 2017:21).

Hal tersebut memungkinkan publik untuk membanding-bandingkan berbagai informasi yang telah didapat dan diterima. Publik berusaha membandingkan antara satu organisasi dengan organisasi lainnya adalah untuk mengetahui apakah organisasi tersebut telah memenuhi harapan publik atau tidak (Kriyantono, 2014:191). Menurut Coombs (2007: 164) Kegagalan organisasi dalam memenuhi harapan publik akan memunculkan kesenjangan pengharapan (expectation gap) yang dapat mengancam reputasi perusahaan.

SCCT menjelaskan bahwa ada tiga variabel yang dapat membentuk reputasi organisasi baik positif maupun negati. Pada dasarnya, variabel ini digunakan praktisi PR untuk membantu mereka dalam mengetahui dan menentukan situasi aktual dalam suatu krisis yang menjadi dasar penentuan strategi respons untuk mengatasi krisis. Ketiga variabel tersebut, yaitu (Coombs, 2007:166-168, Kriyantono, 2014:193):

1. Penanggung jawab krisis pertama (initial crisis responsibility), variabel ini melihat seberapa besar kepercayaan publik bahwa krisis yang terjadi merupakan murni karena kesalahan perilaku yang dilakukan oleh organisasi.

2. Sejarah krisis (crisis history), variabel ini melihat apakah organisasi tersebut mempunyai pengalaman situasi krisis yang sama di masa lalu atau tidak.

3. Reputasi organisasi sebelumnya (prior relational reputation), variabel ini melihat persepsi 
publik tentang bagaimana perlakuan organisasi terhadap korban pada situasi sebelumnya. Menurut teori ini, apabila sebuah organisasi tidak memperlakukan publik dengan baik pada situasi sebelumnya, dapat dipastikan bahwa organisasi itu memiliki prior relational reputation yang buruk.

Atribusi publik tentang siapa yang bertanggung jawab terhadap krisis pada dasarnya dapat dikelompokkan menjadi tiga kelompok klaster (Coombs, 2007: 171, Kriyantono, 2014:194) yakni:

1. Klaster korban (victim cluster), organisasi dikategorikan ke dalam klaster korban jika publik meyakini bahwa organisasi bukanlah penyebab krisis.

2. Klaster tanpa kesengajaan (accidental cluster), muncul ketika publik meyakini bahwa peristiwa yang terjadi bukanlah kesengajaan yang dilakukan organisasi.

3. Klaster kesengajaan (intentional cluster), terjadi jika organisasi diatribusikan sebagai penyebab terjadinya krisis.

Klaster-klaster tersebut akan mencerminkan atribusi publik tentang siapa pihak yang menyebabkan timbulnya situasi krisis. Selanjutnya, pihak yang sudah ditentukan haruslah bertanggung jawab terhadap situasi krisis yang terjadi. Terlepas dari bagaimana atribusi publik, PR tetap dituntut untuk mampu memahami situasi krisis yang ada dan membentuk strategi komunikasi terhadap krisis tersebut guna mengubah persepsi tentang organisasi dalam situasi krisis serta mengurangi dampak negatif yang ditimbulkan oleh krisis (Coombs, 2007:171).

Lebih lanjut SCCT merumuskan dua ketegori dalam merespon krisis, yakni strategi respons primer (primary crisis response strategies) dan strategi respons sekunder (secondary crisis response strategies). Strategi respon primer sendiri dibagi ke dalam tiga kelompok diantaranya: (1) penyangkalan (denial), berusaha untuk tidak mengaitkan organisasi dengan krisis (2) pengurangan (diminish), mencoba memperkuat pandangan bahwa organisasi mempunyai tanggung jawab yang rendah terhadap krisis, dan (3) pembangunan kembali (rebuild), berusaha untuk menciptakan informasi yang positif terkait organisasi. 
Tabel 1

Strategi Respon Krisis SCCT (Coombs, 2017: 24)

\begin{tabular}{|c|c|}
\hline \multicolumn{2}{|c|}{ Strategi Respon Krisis Primer (Primary Crisis Response Strategy) } \\
\hline \multirow[t]{3}{*}{$\begin{array}{c}\text { Penolakan } \\
\text { (Deny) }\end{array}$} & $\begin{array}{l}\text { Menyerang penuduh (attack the accus- } \\
\text { er): PR mereka yang menuduh organisasi } \\
\text { bersalah }\end{array}$ \\
\hline & $\begin{array}{l}\text { Menyangkal (denial): PR menolak menye- } \\
\text { but adanya krisis }\end{array}$ \\
\hline & $\begin{array}{l}\text { Kambing hitam (scapegoating): PR me- } \\
\text { nyalahkan pihak lain di luar organisasinya } \\
\text { atas adanya krisis }\end{array}$ \\
\hline \multirow[t]{2}{*}{$\begin{array}{l}\text { Pengurangan } \\
\text { (Diminish) }\end{array}$} & $\begin{array}{l}\text { Beralasan (excuse): PR meminimalisir } \\
\text { tanggung jawab organisasi dengan me- } \\
\text { nyangkal bahwa organisasi tidak mungkin } \\
\text { dengan sengaja menyebabkan krisis atau } \\
\text { krisis terjadi di luar kendali organisasi }\end{array}$ \\
\hline & $\begin{array}{l}\text { Justifikasi (justification): PR meminimali- } \\
\text { sir persepsi tentang kerusakan atas adan- } \\
\text { ya krisis }\end{array}$ \\
\hline \multirow[t]{2}{*}{ Pembangunan Kembali (Rebuild) } & $\begin{array}{l}\text { Kompensasi (compensation): PR mem- } \\
\text { berikan bantuan kepada korban berupa } \\
\text { uang atau hadiah yang lainnya }\end{array}$ \\
\hline & $\begin{array}{l}\text { Permintaan maaf (apology): PR secara } \\
\text { terbuka bertanggung jawab atas krisis dan } \\
\text { meminta maaf kepada public }\end{array}$ \\
\hline \multicolumn{2}{|c|}{ Strategi Respon Krisis Sekunder (Secondary Crisis Response Strategy) } \\
\hline \multirow[t]{3}{*}{$\begin{array}{c}\text { Penguatan } \\
\text { (Bolstering) }\end{array}$} & $\begin{array}{l}\text { Pengingat (reminder): PR memberi tahu } \\
\text { stakeholder atau publik tentang prestasi } \\
\text { organisasi }\end{array}$ \\
\hline & $\begin{array}{l}\text { Memuji (ingratiation): PR memuji dan } \\
\text { berterimakasih kepada stakeholder atas } \\
\text { bantuan mereka selama krisis }\end{array}$ \\
\hline & $\begin{array}{l}\text { Korban (victimage): PR menjelaskan ke- } \\
\text { pada stakeholder bahwa organisasi juga } \\
\text { termasuk korban dari krisis yang ada }\end{array}$ \\
\hline
\end{tabular}

Strategi respons krisis yang dianggap paling aman adalah strategi membangun kembali (rebuild), di mana pada strategi ini korban diperlakukan dengan lebih baik, meski di sisi lain strategi ini memakan biaya yang relatif besar dengan jaminan reputasi yang belum tentu membaik. Namun bagaimanapun juga prinsip pertama dalam manajemen komunikasi krisis adalah meletakkan prioritas utama pada keselamatan dan kepentingan publik atau stakeholder, 
bukan untuk mempertahankan profit (Kriyantono, 2015:237)

Penguatan (bolstering) dianggap sebagai strategi sekunder yang tidak boleh digunakan sendirian, di mana strategi ini melibatkan upaya untuk memuji pihak-pihak yang membantu dalam krisis atau untuk mengingatkan para stakeholder atas prestasi yang dicapai organisasi. Jika diterapkan secara bersamaan dengan strategi pembangunan kembali (rebuild), strategi penguatan (bolstering) akan menciptakan persepsi positif dari organisasi (Coombs, 2017:25)

Secara lebih jelas Coombs (2007:173) memberikan panduan tentang bagaimana strategi-strategi diatas diaplikasikan sesuai dengan jenis atribusi yang ada pada tanggung jawab krisis, diantaranya:

1. Memberikan dan menyesuaikan informasi saja sudah cukup dilakukan ketika atribusi tentang tanggung jawab krisis yang sedikit (victim cluster), tanpa ada sejarah krisis, dan reputasi hubungan awal bersifat netral atau positif.

2. Strategi korban (victimage) dapat diaplikasikan sebagai respon terhadap kekerasan kerja, cacat produk, bencana alam, dan rumor.

3. Strategi pengurangan (diminish) sebaiknya diaplikasikan pada krisis yang menghasilkan atribusi tentang tanggung jawab krisis yang sedikit (victim cluster), adanya sejarah krisis, dan/atau reputasi hubungan awal bersifat netral atau positif.

4. Strategi pengurangan (diminish) sebaiknya diaplikasikan pada krisis yang menghasilkan atribusi tentang tanggung jawab krisis yang lemah (accidental cluster), tanpa ada sejarah krisis, dan reputasi hubungan awal bersifat netral atau positif.

5. Strategi pembangunan kembali (rebuild) sebaiknya diaplikasikan pada krisis yang menghasilkan atribusi tentang tanggung jawab krisis yang lemah (accidental cluster), adanya sejarah krisis, dan/atau reputasi hubungan awal yang negatif.

6. Strategi pembangunan kembali (rebuild) sebaiknya diaplikasikan pada krisis yang menghasilkan atribusi tentang tanggung jawab krisis yang kuat (intentional cluster), tanpa memperhatikan sejarah krisis dan reputasi hubungan awal.

7. Jika memungkinkan strategi penolakan (deny) sebaiknya diaplikasikan pada krisis seperti rumor dan tuduhan

8. PR harus menjaga konsistensi dalam menggunakan strategi respon krisis. Perlu diketahui bahwa jika PR menggabungkan strategi penolakan (deny) dengan strategi pengurangan (dimish) atau strategi pembangunan kembali (rebuild), efektivitas dari seluruh respon krisis akan menurun.

\section{Metode Penelitian}

Pendekatan penelitian yang digunakan dalam penelitian ini adalah pendekatan kualitatif dengan tipe penelitian deskriptif. Rakhmat (1989:34-35) mendefinisikan penelitian deskriptif sebagai penelitian yang memaparkan situasi atau peristiwa. Dengan tujuan mengumpulkan 
informasi actual secara rinci yang melukiskan gejala-gejala yang ada. Penelitian deskriptif menitik beratkan pada observasi dan suasana alamiah (naturalistic setting), di mana peneliti hanya bertindak sebagai pengamat.

Metode penelitian yang digunakan dalam penelitian ini adalah studi kasus, di mana menurut (Yin, 2003:1) studi kasus merupakan sebuah metode yang mengacu pada penelitian yang mempunyai unsur how dan why pada pertanyaan utama penelitiannya dan meneliti masalah-masalah kontemporer (masa kini) serta sedikitnya peluang peneliti dalam mengontrol peristiwa (kasus) yang ditelitinya. Menurut Denzin dan Lincoln (2005:379) data dari studi kasus sendiri bisa bersumber dari wawancara, pengamatan, dan atau analisis dokumen. Adapun pada penelitian ini data dikumpulkan dari dokumen berupa press release dan pemberitaan terkait kasus jatuhnya pesawat Lion Air JT610 yang diperoleh dari berbagai media. Dokumendokumen yang ada akan di analisis dan dikategorikan kedalam strategi respon krisis yang ada dalam SCCT .

\section{Hasil dan Pembahasan}

\subsection{Peran PR PT. Lion Mentari Airlines dalam Komunikasi Krisis}

Kecelakaan yang menimpa pesawat Lion Air JT610 dengan rute penerbangan Jakarta menuju Pangkal Pinang 29 Oktober lalu merupakan krisis bagi PT. Lion Mentari Airlines. Berdasarkan pembacaan kotak hitam atau black box pesawat jenis Flight Data Recorder (FDR) oleh Komite Nasional Keselamatan Transportasi (KNKT), jatuhnya pesawat yang memakan korban sebanyak 189 orang ini bukan disebabkan oleh masalah mesin melainkan pesawat yang mengalami stall atau kehilangan daya angkat karena perbedaan pembacaan Angle of Attack (AOA) pada sistem milik kapten dan kopilot (viva.com, 22 November 2018). Krisis karena jatuhnya pesawat seperti ini Menurut Morissan (2006:154) termasuk ke dalam tipe krisis yang bersifat segera (immediate crisis), di mana krisis ini merupakan krisis yang paling ditakuti karena terjadi begitu tiba-tiba, tidak terduga dan tidak diharapkan. Krisis jenis ini membutuhkan konsensus terlebih dahulu pada tingkat manajemen puncak guna mempersiapkan rencana umum (general plan) mengenai bagaimana bereaksi agar tidak terjadi kebingungan, konflik dan penundaan dalam mengenai krisis yang muncul.

PR PT. Lion Mentari Airlines merespon immediate crisis tersebut dengan segera menyediakan layanan pusat krisis (crisis center) yang dibarengi dengan pernyataan keprihatinan mereka atas kecelakaan ini dengan mengubah seluruh akun media sosial mereka mulai dari dari Twitter, Facebook dan Instagram hingga situs resminya menjadi hitam putih (detik.com, 29 Oktober 2018). Melalui pusat krisis yang berlokasi di Terminal 1 Bandara Internasional Soekarno - Hatta di Tangerang, Bandara Halim Perdanakusuma, Jakarta Timur dan Bandara Depati Amir, Pangkal Pinang, Kepulauan Bangka Belitung, Lion Air mengumpulkan keluarga korban untuk mendapatkan informasi terkait perkembangan kecelakaan yang ada. pusat krisis 
ini juga bisa dihubungi melalaui nomor 021-80820001 yang sebelumnya sudah di publikasikan melalui press release yang ada di akun sosial media mereka. Menurut Wasesa (dalam Sagala, 2015:50-51) pusat penanggulangan krisis sendiri pada dasarnya berguna untuk kepentingan publik yang berhubungan dengan krisis atau kecelakaan yang dihadapi, dalam kasus ini pusat krisis memang perlu disediakan untuk kepentingan para keluarga korban Lion Air JT610. Selain pusat krisis, pihak Lion Air juga memberikan nomor yang bisa dihubungi terkait informasi penumpang di 021-80820002.

Selain mendirikan pusat krisis dan membuat press release serta meng-update-nya secara berkala, PR PT. Lion Mentari Airlines pada hari itu juga melakukan konferensi pers (press conference) untuk menjelaskan informasi dan perkembangan terkait kecelakaan yang ada serta kebijakan-kebijakan yang tengah diambil manajemen dalam menanggapi krisis tersebut. CEO PT. Lion Mentari, Edward Sirait ditunjuk sebagai juru bicara (spokesperson) dalam konferensi pers yang diadakan di Gedung Lion Air Operation Center, Tangerang. Selain PR, CEO adalah komunikator yang dianggap memiliki kredibilitas dan news value yang tinggi terkait krisis yang ada (Kriyantono, 2015:252)

Dalam konferensi tersebut terlihat bahwa Lion Air sangat hati-hati dalam memberikan informasi kepada publik, di mana mereka tidak mau berspekulasi tentang penyebab kecelakaan pesawat sebelum bukti nyata berhasil dikumpulkan dari investigasi. Seperti apa yang di ungkapkan oleh Kriyantono (2015:250-251) situasi krisis desakan media (media scrutiny) sangat besar, namun perusahaan tidak perlu terburu-buru menyampaikan informasi yang masih belum jelas atau belum mempunyai fakta yang valid. Di konferensi tersebut banyak sekali media yang yang menekan pihak Lion Air untuk memberikan konfirmasi terkait alasan jatuhnya pesawat, namun pihak Lion Air menjawab dengan bijak bahwa fact finding yang masih berlangsung.

Lebih lanjut pihak Lion Air mengaku merasa berduka dan terpukul atas kecelakaan ini karena bagaimanapun juga menurut mereka siapapun yang ada di dalam pesawat tersebut merupakan saudara dan mereka tidak menginginkan hal ini terjadi Selain itu dalam konferensi ini pihak Lion Air juga menjelaskan bahwa mereka sudah mendirikan posko untuk keluarga korban dan memfokuskan kegiatan pada bantuan bagi keluarga korban seperti memberikan akomodasi dan informasi yang dibutuhkan. Wujud rasa empati ini merupakan salah satu prinsip dari strategi komunikasi krisis yang harus diterapkan oleh PR, di mana menurut Kriyantono (2015:252) meskipun krisis bukan kesalahan organisasi, kata maaf, keprihatinan atau kesedihan yang mendalam perlu disampaikan.

Berdasarkan pernyataan Edward Sirait dalam konferensi pers, diketahui bahwa strategi respon krisis primer yang digunakan oleh PR PT. Lion Mentari Airlines saat pertama kali krisis ini muncul adalah strategi pengurangan (diminish) yang terdiri dari excuse dan pembangunan kembali (rebuild) yang terdiri dari compensation apology dan compensation. Selanjutnya 
selama dalam penanganan kecelakaan ini berdasarkan press release dan pemberitaan di media, PR PT. Lion Mentari juga menggunakan strategi respon krisis sekunder seperti memuji (ingratiation) serta strategi korban (victimage) yang sebelumnya sudah dilakukan saat konferensi pers.

Tabel 2

Temuan Hasil Penelitian

\begin{tabular}{|c|c|}
\hline \multicolumn{2}{|c|}{ Strategi Respon Krisis Primer (Primary Crisis Response Strategy) } \\
\hline \multirow{3}{*}{$\begin{array}{c}\text { Penolakan } \\
\text { (Deny) }\end{array}$} & Menyerang penuduh (attack the accuser) \\
\hline & Menyangkal (denial) \\
\hline & Kambing hitam (scapegoating) \\
\hline \multirow{2}{*}{$\begin{array}{l}\text { Pengurangan } \\
\text { (Diminish) }\end{array}$} & Beralasan (excuse)* \\
\hline & Justifikasi (justification) \\
\hline \multirow[t]{2}{*}{ Pembangunan Kembali (Rebuild) } & Kompensasi (compensation)* \\
\hline & Permintaan maaf (apology)* \\
\hline \multicolumn{2}{|c|}{ Strategi Respon Krisis Sekunder (Secondary Crisis Response Strategy) } \\
\hline \multirow{3}{*}{$\begin{array}{l}\text { Penguatan } \\
\text { (Bolstering) }\end{array}$} & Pengingat (reminder) \\
\hline & Memuji (ingratiation)* \\
\hline & Korban (victimage)* \\
\hline
\end{tabular}

*) Strategi respon krisis yang dilakukan oleh PR PT. Lion Mentari Airlines terkait kasus jatuhnya pesawat Lion Air JT610

\subsection{Strategi Respon Krisis Primer Pengurangan: Excuse}

Strategi respon krisis primer yang pertama kali di lakukan oleh PR PT. Lion Mentari Airlines adalah excuse, di mana strategi pengurangan respon krisis ini ditunjukkan melalui pernyataan Edward Sirait, selaku CEO maskapai Lion Air yang menjadi spokesperson dalam konferensi pers. Edward Sirait menyebutkan bahwa kecelakaan tersebut merupakan hal yang tak terduga dan di luar kontrol perusahaan. la menyatakan bahwa pesawat Lion Air JT610 tersebut merupakan pesawat yang baru dan layak terbang. Selain itu ia juga menambahkan bahwa pilot dan kopilot yang bertugas juga sudah berpengalaman, di mana pilot sudah memiliki jam terbang lebih dari 6.000 jam terbang dan kopilot telah mempunyai jam terbang lebih dari 5.000 jam terbang. Keduanya adalah penerbang yang sangat berpengalaman, juga dalam menerbangkan pesawat ke luar negeri seperti ke Cina dan Timur Tengah. Melalui konferensi pers tersebut juga diketahui memang ada laporan mengenai masalah teknis sebelum pesawat diberangkatkan, namun hal tersebut sudah dikerjakan sesuai dengan prosedur maintenance yang dikeluarkan oleh pabrikan pesawat. Merujuk pada SCCT apa yang dikatakan oleh Edward Sirait tersebut merupakan alasan-alasan yang menujukkan penyangkalan bahwa organisasi 
dengan sengaja menyebabkan krisis atau dengan kaata lain kecelakaan terjadi di luar kendali organisasi

Menurut Coombs (2007:173) Strategi pengurangan (diminish) memang sebaiknya diaplikasikan pada krisis yang menghasilkan atribusi tentang tanggung jawab krisis yang lemah (accidental cluster), namun pihak Lion Air tetap menggunakan strategi saat atribusi tentang tanggung jawab krisis yang kuat (intentional cluster) muncul di masyarakat karena memang belum ada fakta dari hasil investigasi yang membuktikan bahwa penyebab jatuhnya pesawat merupakan kesalahan maskapai, dengan begitu atribusi yang sebelumnya kuat di masyarakat bisa diturunkan levelnya menjadi lemah.

\subsection{Strategi Respon Krisis Primer Pembangunan Kembali: Compensation dan Apology}

Strategi respon krisis primer lain yang di lakukan oleh PR PT. Lion Mentari Airlines adalah compensation dan apology. Kedua strategi ini termasuk ke dalam kategori strategi pembangunan kembali (rebuild) yang menurut Coombs (2007:173) sebaiknya diaplikasikan pada krisis yang menghasilkan atribusi tentang tanggung jawab krisis yang lemah (accidental cluster) sebagaimana yang diharapkan dari strategi excuse yang dilakukan oleh Lion Air sebelumnya, mengingat reputasi Lion Air juga memang kurang baik di mata masyarakat. Wujud dari strategi kompensasi yang dilakukan oleh pihak Lion Air adalah dengan memberikan uang sebesar 5 juta bagi para keluarga yang sedang menunggu jalannya investigasi di posko-posko dan pusat krisis. Kompensasi tersebut diberikan sebagai ganti biaya hidup para keluarga korban selama berada di posko. Selain itu berdasarkan press release yang dimuat di akun sosial media mereka, Lion Air juga memberikan kompensasi sebesar 125 juta untuk biaya pemakaman korban yang sudah terindentifikasi.

Dua kompensasi tersebut merupakan kompensasi di luar kompensasi wajib yang harus dibayarkan Lion Air sesuai undang-undang, di mana Lion Air akan memberikan total santunan kepada setiap keluarga korban jatuhnya pesawat senilai Rp 1,3 miliar. Jumlah tersebut merupakan gabungan dari santunan sebesar $\mathrm{Rp}$ 1,25 miliar sesuai dengan Peraturan Menteri Perhubungan Nomor 77 Tahun 2011 tentang Tanggung Jawab Pengangkut Angkutan Udara dan asuransi bagasi senilai Rp 50 juta (tempo.co, 4 November 2018). Jika dilihat dari kacamata SCCT, pemberian kompensasi dari pihak Lion Air tersebut merupakan upaya PR untuk menjamin keselamatan dan keamanan publik serta stakeholder yang menjadi prioritas utama dalam komunikasi krisis, di mana pada gilirannya akan membangun atribusi positif dari publik terhadap reputasi perusahaan (Kriyantono, 2014:190).

Sementara itu untuk strategi apology pihak Lion Air dengan secara terbuka bertanggung jawab atas krisis dan meminta maaf secara langsung kepada korban melalui pernyataan yang diucapkan oleh Rusdi Kirana selaku pendiri Lion Air. Ia juga mengatakan bahwa Lion Air siap untuk diaudit karena kecelakaan tersebut, termasuk menerima sanksi bila ditemukan ada kesalahan 
manajemen (kompas.com, 31 Oktober 2018). Tanggung jawab ini dilakukan oleh pihak Lion Air dengan melakukan pencarian dan evakuasi korban selama sepuluh hari bersama BASARNAS dan stakeholder lainnya, dalam pencarian ini total korban yang sudah teridentifikasi 125 jenazah, dengan rincian laki-laki 90 orang dan wanita 35 orang (lionair.co.id, 28 Oktober 2018). Tanggung jawab atas krisis ini juga dilakukan oleh Lion Air melalui pendampingan psikologi kepada seluruh keluarga korban (family assistance) di posko-posko dan pusat krisis.

\subsection{Strategi Respon Krisis Sekunder Penguatan: Ingratiation dan Victimage}

Selain strategi respon krisis primer, pihak Lion Air juga melakukan strategi respon krisis sekunder berupa ingratiation atau memuji dan berterimakasih kepada stakeholder yang diwujudkan melalui ucapan terimakasih pihak Lion Air yang dimuat dalam press release disertai dengan video dramatis keluarga korban ketika mengunjungi lokasi jatuhnya pesawat di perairan Tanjung Pakis, Karawang, Jawa Barat dengan caption "Kami akan terus selalu ada mendampingi keluarga korban yang ditinggalkan. Kami juga mengucapkan terima kasih untuk semua pihak yang terlibat dalam proses penanganan tragedi ini dan semoga selalu diberikan kekuatan dan keselamatan hingga semua selesai". Selama melakukan investigasi dan evakuasi korban kecelakaan Lion Air JT610, pihak Lion Air banyak dibantu oleh BASARNAS, TNI, Kementerian Perhubungan, KNKT dan DVI Polri serta para relawan. Selain itu dalam posko-posko pusat krisis Lion Air juga dibantu oleh beberapa pihak seperti Himpunan Psikologi Indonesia, Psikologi POLRI, Psikologi AU dan Yayasan Buddha Tzu Chi untuk mendampingi para keluarga korban. Secara tidak langsung dalam krisis ini Lion Air telah memunculkan banyak stakeholder yang membantu proses pengendalian krisis mereka.

Untuk strategi respon krisis sekunder penguatan jenis victimage pihak Lion Air sudah menerapkannya sejak mereka melakukan konferensi pers, di mana jika dipahami lebih lanjut, pernyataan Edward Sirait selaku CEO dan spokesperson yang menganggap mereka yang ada di dalam pesawat merupakan saudara, sehingga mereka juga merasa berduka dan terpukul atas kecelakaan tersebut, serta mereka juga tidak menginginkan hal ini terjadi adalah bentuk dari victimage yang pada dasarnya menjelaskan kepada stakeholder atau public bahwa perusahaan juga termasuk korban dari krisis yang ada. Status "juga korban" ini mengalami penguatan saat KNKT melakukan pembacaan kotak hitam atau black box pesawat dan menemukan bahwa pesawat yang terjatuh karena mengalami stall atau kehilangan daya angkat disebabkan karena perbedaan pembacaan angle of attack pada sistem milik kapten dan kopilot. Hal tersebut diduga terjadi karena tidak adanya informasi kepada maskapai terkait sistem automated stallprevention dalam sensor angle of attack pada pesawat Boeing seri 737 Max 8 yang dipakai oleh Lion Air JT610. Pasca kecelakaan ini sendiri pihak Boeing kemudian membuat buletin yang ditujukan ke seluruh operator penerbangan tentang bagaimana mengatasi mallfunction tersebut (cbsnews.com, 7 November 2018). 


\section{Simpulan dan Saran}

Berdasarkan hasil temuan dan diskusi diatas dapat disimpulkan bahwa strategi yang dilakukan oleh PR PT. Lion Mentari Airlines dalam mengelola krisis akibat jatuhnya pesawat Lion Air JT610 merupakan gabungan antara strategi respon krisis primer pengurangan (diminish) dan pembangunan kembali (rebuild). Strategi pengurangan dilakukan melalui penyampaian alasan-alasan saat konferensi pers. Sementara itu strategi pembangunan kembali dilakukan melalaui pemberian kompensasi dan permintaan maaf secara langsung kepada keluarga korban. Selain melakukan startegi primer PR PT. Lion Mentari Airlines juga melakukan strategi respon krisis sekunder berupa strategi memuji (ingratiation) dan strategi korban (victimage). Strategi memuji dilakukan melalaui ucapan terimakasih terhadap seluruh pihak seperti BASARNAS, TNI, Kementerian Perhubungan, KNKT dan DVI Polri serta para relawan atau stakeholder yang membantu saat krisis terjadi. Sementara itu untuk strategi korban dilakukan pihak Lion Air dengan merasa berduka dan terpukul atas kecelakaan yang ada dengan mengatakan bahwa mereka yang ada dipesawat merupakan saudara dan mereka juga tidak menginginkan hal tersebut terjadi.

Berdasarkan hasil temuan dan diskusi yang ada pada penelitian ini juga, saran yang bisa diberikan oleh peneliti untuk penelitian selanjutnya adalah dengan melakukan analisis yang lebih mendalam terhadap pemanfaatan media sosial korporat sebagai media komunikasi krisis. Di mana selain memudahkan pemusatan informasi, dalam komunikasi krisis yang menuntut kejelasan dan kecepatan akan informasi yang dibutuhkan, media sosial dinilai lebih lebih efektif dan efesien serta mampu menampung respon publik terhadap komunikasi krisis itu sendiri.

\section{Daftar Pustaka}

Barton, L. (1993). Crisis in Organizations: Managing and Communications in the Heat of Chaos. Ohio: South-Western Publishing.

BBC Indonesia . (2018). Lion Air JT610: Mengapa Pesawat yang Masih Begitu Baru Bisa Jatuh? Diakses melalui https://www.bbc.com/indonesia/indonesia-46021789 Pada tanggal 19 November 2018 Pukul 16:03 WIB

Coombs, W. T. (2007). Protecting Organization Reputations During a Crisis: The Development and Application of Situational Criss Communication Theory. Corporate Reputation Review, Vol. 1 No. 3. Hal: 163-176.

Coombs, W. T. (2017). Revising Situational Crisis Communication Theory. Social Media and Crisis Communication, Vol. 1 Hal: 21-37.

Denzin, N. K., dan Lincoln, Y. S. (2005). The SAGE Handbook of Qualitative Research $3^{\text {rd }}$ Edition. Sage Publication 
Djumena, E. (2013). Usai Malaysia, Lion Air Ekspansi ke Thailand. Diakses melalui https:// ekonomi.kompas.com/read/2013/08/20/1021597/Usai.Malaysia.Lion.Air.Ekspansi. ke.Thailand Pada tanggal 19 November 2018 Pukul 15:17 WIB

Fearn-Banks, K. (2007). Crisis Communications: A Casebook Approach, 3rd Edition. London: Routledge.

Haryanto, T. A. (2018) \#JT610 Tembus Jadi Topik Populer di Dunia. Diakses melalui_https://inet. detik.com/cyberlife/d-4278028/it610-tembus-jadi-topik-populer-di-dunia Pada tanggal 19 November 2018 Pukul 15:34 WIB

Ihsanuddin. (2018). KNKT: Pesawat Lion Air yang Jatuh Masih Sangat Bar. Diakses melalui https://nasional.kompas.com/read/2018/10/29/10452421/knkt-pesawat-lion-air-yangjatuh-masih-sangat-baru Pada tanggal 19 November 2018 Pukul 15:58 WIB

Indrayani, H. (2017). Etika Advokasi Public Relations dalam Manajemen Krisis Reputasi. Interaksi: Jurnal Ilmu Komunikasi. Vol. 5 No.1 Hal: 68-77

Josina. (2018). Berduka, Akun Medsos Lion Air Hitam Putih Diakses melalui https://inet.detik. com/cyberlife/d-4278209/berduka-akun-medsos-lion-air-hitam-putih Pada tanggal 19 November 2018 Pukul 14:22 WIB

Kriyantono, R. (2014). Teori Public Relations Perspektif Barat \& Lokal: Aplikasi Penelitian dan Praktik. Jakarta: Kencana

Kriyantono, R. (2015). Public Relations \& Krisis Management: Pendekatan Critical Public Relations Etnografi Kritis \& Kualitatif. Jakarta: Kencana

Mashabi, S. (2018). YLKI: Aduan Penumpang Terhadap Pelayanan Lion Air Tertinggi. Diakses melalui https://www.liputan6.com/news/read/3683350/ylki-aduan-penumpangterhadap-pelayanan-lion-air-tertinggi Pada tanggal 19 November 2018 Pukul 13:37 WIB

Moetri dan Sari (2014). 4 Strategi AirAsia perketat persaingan dengan Lion Air. Diakses melalui https://www.merdeka.com/uang/4-strategi-airasia-perketat-persaingan-dengan-lionair.html Pada tanggal 19 November 2018 Pukul 15:08 WIB

Moore, H. dan Coe C. (2018). Australians Are Urged Not to Fly with Lion Air After One of the Airline's Jets Crashes North of Indonesia with 189 People on Board. Diakses melalui https://www.dailymail.co.uk/news/article-6328363/Australians-urged-not-fly-Lion-Airjets-crashes-north-Indonesia.html Pada tanggal 23 November 2018 Pukul 15:24 WIB

Morissan. (2006). Pengantar Public Relations Strategi Menjadi Humas Profesional. Bandung: Ramdina Prakarsa

Nistanto. (2018). Lion Air JT 610, Kecelakaan Pesawat Terparah di Indonesia Sejak 1997. Diakses melalui_https://tekno.kompas.com/read/2018/10/31/11070037/lion-air-jt610-kecelakaan-pesawat-terparah-di-indonesia-sejak-1997 Pada tanggal 19 November 2018 Pukul 13:24 WIB 
Pertiwi, W. K. (2018). 4 Hoaks Kecelakaan Lion Air JT 610 beserta Klarifikasinya. Diakses melalui https://tekno.kompas.com/read/2018/10/30/12155697/4-hoaks-kecelakaan-lion-airjt-610-beserta-klarifikasinya Pada tanggal 19 November 2018 Pukul 15:44 WIB

Picchi A. (2018). Boeing 737 Max 8 Safety Alert Issued After Deadly Lion Air Crash. Diakses melalui https://www.cbsnews.com/news/boeing-737-max-8-safety-alert-lion-air-crashinvestigation-today-2018-11-07/ Pada tanggal 23 November 2018 Pukul 15:15 WIB

Praditya. (2015). Sering Delay, Kenapa Tiket Lion Air Tetap Laris Manis? Diakses melalui https:// www.liputan6.com/bisnis/read/2179045/sering-delay-kenapa-tiket-lion-air-tetap-larismanis Pada tanggal 19 November 2018 Pukul 15:14 WIB

Prayudi, P. (1998). Strategi Komunikasi Organisasi dalam Menghadapi Krisis. Paradigma: Jurnal Masalah Sosial, Politik dan Kebijakan, Vol. 2 No. 6. Hal: 31-42.

Primus, J. (2018). Pada 2020, Indonesia Masuk 10 Besar Pasar Penerbangan Dunia. Diakses melalui_https://ekonomi.kompas.com/read/2016/04/20/201938626/Pada.2020. Indonesia.Masuk.10.Besar.Pasar.Penerbangan.Dunia. Pada tanggal 19 November 2018 Pukul 13:28 WIB

Rachmatunnisa. (2018). Tiga Hoax yang Teridentifikasi Kominfo Terkait Lion Air JT 610. Diakses melalui https://inet.detik.com/cyberlife/d-4280158/tiga-hoax-yang-teridentifikasikominfo-terkait-lion-air-jt-610 Pada tanggal 19 November 2018 Pukul 145:47 WIB

Rakhmat, J. (1989), Metode Penelitian Komunikasi, Bandung: Remaja Rosdakarya

Sagala, R. (2015). Strategi Kominikasi Public Relations Lion Air Dalam Menghadapi Krisis Delay Berkepanjangan Di Bandara Soekarno Hatta. (2015). Jurnal Fessospol Jendela. Vol. 3 No. 2 Hal: 47-57

Siddiq, T. (2018). Lion Air: Setiap Korban Akan Menerima Kompensasi Rp 1,3 Miliar. Diakses melalui. $\quad$ https://nasional.tempo.co/read/1142986/lion-air-setiap-korban-akanmenerima-kompensasi-rp-13-miliar Pada tanggal 23 November 2018 Pukul 15:28 WIB

Sukmana, Y. (2018). Rusdi Kirana soal JT-610, dari Minta Maaf hingga Siap Disanksi. Diakses melalui https://nasional.kompas.com/read/2018/10/31/10195011/rusdi-kirana-soal-jt610-dari-minta-maaf-hingga-siap-disanksi Pada tanggal 23 November 2018 Pukul 15:04 WIB

Widiarini, A. dan Berlian, I. (2018). Daftar Maskapai Termurah Dunia, 3 Asal Indonesia. Diakses melalui https://www.viva.co.id/gaya-hidup/travel/1040262-daftar-maskapai-termurahdunia-3-asal-indonesia Pada tanggal 19 November 2018 Pukul 15:04 WIB

Yin, R. K. (2003). Case Study Research Design and Methods $3^{\text {rd }}$ Edition. London: Sage Publication. Yuliawati dan Fajri. (2018). KNKT Beberkan Kronologi Lion Air JT610 Alami Stall. Diakses melalui https://www.viva.co.id/berita/nasional/1096603-baca-kotak-hitam-knkt-beberkankronologi-lion-air-jt610-alami-stall Pada tanggal 23 November 2018 Pukul 15:32 WB 